\title{
ANALISIS PERILAKU PENCEGAHAN PENULARAN HIV/AIDS DENGAN PENDEKATAN HEALTH BELIEF MODEL (HBM) PADA WBP DI LAPAS KELAS IIA PADANG
}

\author{
Sri Mindayani ${ }^{1}$, Hilda Hidayat ${ }^{2}$ \\ ${ }^{1,2}$ Fakultas Kesehatan Masyarakat Universitas Baiturrahmah. \\ Email: ${ }^{1}$ sri.mindayani@gmail.com, ${ }^{2}$ hildahidayat15@gmail.com
}

\begin{abstract}
Abstrak
Data prevalensi Surveilans Terpadu Biologis dan Perilaku Kementerian Kesehatan tahun 2011 ditemukan angka prevalensi HIV dan sifilis di kalangan narapidana yaitu 3\% dan 5\%. Adapun tujuan penelitian ini yaitu untuk mengetahui analisis perilaku pencegahan penularan HIV/AIDS dengan pendekatan Health Belief Model (HBM) pada WBP dI LAPAS Kelas IIA Padang. Jenis penelitian ini adalah analitik dengan desain cross sectional. Penelitian ini dilaksanakan dari bulan Januari - September 2018 Lapas Kelas IIA Padang. Populasi penelitian berjumlah dengan 1375 orang dan jumlah sampel sebanyak 100 orang. Pengambilan sampel dilakukan dengan teknik simple random sampling. Pengumpulan data primer dilakukan dengan teknik wawancara menggunakan kuesioner. Analisis data meliputi analisis univariat, bivariat dan multivariat. Hasil penelitian menunjukkan adanya hubungan antara persepsi hambatan dan dorongan dengan perilaku pencegahan penularan HIV/AIDS pada WBP di Lapas Kelas IIA Padang. Hasil penelitian juga menunjukkan tidak adanya hubungan antara pengetahuan, persepsi keparahan, persepsi kerentanan, dan persepsi manfaat dengan perilaku pencegahan penularan HIV/AIDS pada WBP di Lapas Kelas IIA Padang.
\end{abstract}

Kata kunci: Health Believe Model, HIV/AIDS, Perilaku.

\begin{abstract}
Data fromSurveilans Terpadu Biologis dan Perilaku in 2011, found the prevalence of HIV and syphilis among prisoners of $3 \%$ and $5 \%$. Lapas Kelas II A Padang has HIV/AIDS cases. The purpose of this study is to determine the analysis of behavior prevention of HIV / AIDS transmission with the Health Belief Model approach on WBP in Lembaga Pemasyarakatan Kelas IIA Padang. The type of research is analytic with cross sectional design. This research was conducted from January - September 2018 in Lapas Kelas IIA Padang. The population amounted to 1375 people and the number of samples was 100 people. Sampling was done by simple random sampling technique. Primary data collection is done by interview technique using a questionnaire. Data analysis includes univariate, bivariate and multivariate analyzes. The results of the study showed that there was a relationship between perceived barriers and cues to action with the behavior of preventing HIV / AIDS. There was no relationship
\end{abstract}


between knowledge, susceptibility to vulnerability,perception of severity, and perceived benefits with the behavior of preventing HIV / AIDS.

Keywords: Health Belief Model, HIV/AIDS, behavior.

\section{PENDAHULUAN}

Indonesia merupakan negara dengan jumlah kasus HIV paling banyak di Asia Tenggara yaitu diperkirakan 48.000 kasus. Di Asia, Indonesia menempati urutan ketiga terbesar dalam kasus HIV/AIDS (UNAIDS, 2017). Jumlah kasus HIV di Indonesia pada saat ini terus mengalami peningkatan dari tahun ke tahun. Pada tahun 2014 terdapat 32.711 kasus, tahun 2015 terdapat 30.395 kasus dan pada tahun 2016 terdapat 41.250 kasus (Kemenkes RI, 2017).

Komunitas penghuni penjara atau yang menurut istilah resmi dikenal dengan sebutan Lapas (Lembaga Pemasyarakatan) atau Rutan (Rumah Tahanan) merupakan salah satu kelompok masyarakat yang sangat rentan terhadap penularan HIVAIDS (Purba dkk., 2011). Menurut data prevalensi Surveilans Terpadu Biologis dan Perilaku (Kemenkes, 2011), ditemukan angka prevalensi HIV dan sifilis dikalangan narapidana adalah 3\% dan 5\%. Hasil ini mendukung temuan pada Penelitian Kesehatan dan Perilaku narapidana yang dilakukan direktorat Jenderal Pemasyarakatan pada tahun 2010 di 24 Lapas/rutan (13 provinsi), dimana prevalensi HIV dan sifilis pada narapidana pria adalah $1,1 \%$ dan $5,1 \%$, sedangkan pada narapidana wanita lebih tinggi yaitu mencapai $6 \%$ dan 8,5\%. Data dari 2 (dua) sumber tersebut menunjukkan urgensi dalam pengendalian dan pencegahan penularan HIV/AIDS di Lapas/Rutan (Kemenkumham, 2012).

Lembaga Pemasyarakatan (Lapas) Kelas IIA Padang merupakan salah satu lembaga pemasyarakatan yang ada di Provinsi Sumatera Barat. Berdasarkan survey pendahuluan yang dilakukan pada bulan April 2017 kepada dokter penanggungjawab di Lapas Kelas IIA Padang, diketahui terdapat 6 orang WBP (Warga Binaan Pemasyarakatan) yang menderita HIV. Hasil wawancara ini juga diketahui bahwa terdapat salah satu orang nara pidana yang dicurigai meninggal karena HIV/AIDS. Pada Lapas ini tidak ada pemeriksaan HIV/AIDS bagi WBP yang baru memasuki Lapas, sehingga data awal tentang WBP yang terkena HIV/AIDS tidak diketahui. Akan tetapi, jumlah penderita HIV/AIDS baru akan diketahui, ketika dokter penanggungjawab Lapas mencurigai adanya WBP yang menderita HIV/AIDS. Sehingga WBP yang dicurigai akan diperiksakan tes HIV/AIDS. Tidak adanya pemeriksaan HIV/AIDS sebelum WBP masuk ke dalam Lapas akan berisiko untuk meningkatkan penularan HIV/AIDS di Lapas tersebut.

Jumlah WBP di lapas ini pada April 2017 yaitu 1375 orang, yang terdiri dari 1032 orang nara pidana dan 343 orang tahanan. Jumlah WBP ini tidak sesuai dengan kapasitas/daya tampung Lapas yaitu sebanyak 458 orang. Tingkat kepadatan hunian lapas yang lebih banyak 3 kali lipat dari seharusnya, tentunya akan meningkatkan risiko penyakit menular berbasis lingkungan pada WBP yang ada di lapas, tidak menutup kemungkinan juga risiko penularan HIV/AIDS.

Selain itu, dari hasil wawancara dengan petugas Lapas, diketahui bahwa beberapa WBP pernah melakukan tindakan-tindakan yang berisiko untuk terjadinya penularan HIV/AIDS seperti perilaku seksual yang tidak aman (hubungan LSL/Lelaki Suka Lelaki), 
terdapatnya WBP dengan riwayat (Warga Binaan Pemasyarakatan) di pengguna narkotika jenis suntik, Lembaga Pemasyarakatan Kelas IIA terdapatnya WBP yang memiliki tato, Padang yang berjumlah sebanyak 1375 dimana tindakan-tindakan ini adalah orang. Jumlah sampel 100 orang dengan tindakan yang sangat berisiko untuk teknik simple random sampling. Variabel mudahnya WBP tertular penyakit dependen dalam penelitian ini yaitu HIV/AIDS.

Oleh karena adanya beberapa masalah di atas, maka peneliti tertarik untuk melakukan penelitian mengenai "Analisis Perilaku Pencegahan Penularan HIV/AIDS dengan Pendekatan Health Belief Model (HBM) Pada WBP Di Lapas Kelas IIA Padang”.

\section{METODE PENELITIAN}

Penelitian ini bersifat analitik dengan desain cross sectional. Penelitian ini dilaksanakan dari Januari - September 2018 di Lembaga Pemasyarakatan Kelas IIA Padang, Sumatera Barat. Populasi pada penelitian ini adalah seluruh WBP perilaku pencegahan penularan HIV/AIDS dan variabel independen yaitu pengetahuan, persepsi kerentanan, persepsi keparahan, persepsi manfaat, persepsi hambatan dan dorongan. Data di analisis dengan analisis univariat, analisis bivariat, dan multivariat.

\section{HASIL DAN PEMBAHASAN}

\section{a. Hubungan Pengetahuan dengan Perilaku Pencegahan HIV/AIDS}

Hasil penelitian tentang hubungan pengetahuan dengan perilaku pencegahan HIV/AIDS pada WBP (Warga Binaan Pemasyarakatan), didapatkan data di bawah ini:

Tabel 1.

Hubungan Pengetahuan dengan Perilaku Pencegahan Penularan HIV/AIDS pada Warga Binaan Pemasyarakatan (WBP) di Lembaga Pemasyarakatan

Kelas IIA Padang Tahun 2018

\begin{tabular}{|c|c|c|c|c|c|c|c|c|}
\hline \multirow{3}{*}{ No } & \multirow{3}{*}{ Pengetahuan } & \multicolumn{4}{|c|}{$\begin{array}{l}\text { Perilaku Pencegahan } \\
\text { Penularan HIV/AIDS }\end{array}$} & \multirow{2}{*}{\multicolumn{2}{|c|}{ Jumlah }} & \multirow{3}{*}{ P Value } \\
\hline & & \multicolumn{2}{|c|}{ Baik } & \multicolumn{2}{|c|}{ Kurang Baik } & & & \\
\hline & & $\mathbf{F}$ & $\%$ & $\mathbf{F}$ & $\%$ & $\mathbf{F}$ & $\%$ & \\
\hline 1 & Baik & 24 & 24 & 37 & 37 & 61 & 61 & \multirow{3}{*}{0,224} \\
\hline 2 & Tidak Baik & 21 & 21 & 18 & 18 & 39 & 39 & \\
\hline & Jumlah & 45 & 45 & 55 & 55 & 100 & 100 & \\
\hline
\end{tabular}

Hasil uji statistik diperoleh nilai $\mathrm{P}$ Value 0,224 yang berarti tidak terdapat hubungan yang bermakna antara pengetahuan dengan perilaku pencegahan penularan HIV/AIDS.

Penelitian ini sejalan dengan penelitian Erniwaty (2017) didapatkan hasil bahwa pengetahuan mengenai HIV/AIDS tidak memiliki hubungan bermakna dengan perilaku pencegahan HIV/AIDS $(p=0,723)$ dengan interval kepercayaan sebesar 0,756-0,910. Penelitian ini juga sejalan dengan penelitian Handayani (2014) yang menunjukkan bahwa tidak adanya hubungan antara pengetahuan dengan perilaku warga binaan pemasyarakatan dalam pencegahan HIV/AIDS di Lembaga Pemasyarakatan Narkotika Kelas IIA Kota Bandar Lampung tahun 2014. Akan tetapi, penelitian ini tidak sejalan dengan penelitian Nuzillah dan Sukendra (2017) dimana berdasarkan uji chi-square diperoleh nilai $\mathrm{p}=0,013 \quad(\mathrm{p}<0,05)$ yang artinya ada hubungan yang signifikan antara pengetahuan narapidana tentang 
HIV/AIDS dengan perilaku berisiko penularan HIV/AIDS. Hasil penelitian ini juga tidak sejalan dengan penelitian yang dilakukan oleh Nurachmah (2009) di SLTP X Jakarta bahwa proporsi persepsi tentang pengetahuan, sikap dan pencegahan yang baik memberikan kemudahan dalam kemampuan memiliki pemahaman tentang mencegah HIV/AIDS melalui perilaku berisiko tertular pada siswa SLTP.

Menurut Azwar (2013) pengetahuan tidak secara langsung berhubungan dengan suatu perilaku dalam tindakan dan menghasilkan suatu nilai positif. Hal ini disebabkan dalam merespon suatu pengetahuan sebagai hasil penginderaan, diperlukan respon berupa sikap yang baik sehingga mengubah atau membentuk suatu perilaku atau tindakan.

Menurut Festinger dalam Azwar (2013) yang mengemukakan teori 'disonansi kognitif', bahwa ada kecenderungan manusia untuk menghindari perilaku sehingga tidak sesuai dengan sikap atau pengetahuan dapat tidak bersesuaian dengan sikap dan perilaku. Manusia pada dasarnya selalu logis dan terasumsi sehingga berusaha menjaga konsistensi pengetahuan yang telah dimilikinya, namun ternyata harus berhadapan dengan kenyataan bahwa perilaku manusia seringkali irasional. Disonansi kognitif terjadi ketika seseorang memegang dua perilaku yang berbeda atau ketika kepercayaan tidak sejalan dengan perilaku.

Selain itu, menurut Rosenberg dalam Azwar (2013) komponen pengetahuan tidak saja merupakan apa yang diketahui mengenai objek, namun mencakup apa yang dipercayai mengenai hubungan objek sikap dengan nilai afektif. Nilai afektif adalah perasaan seseorang terhadap suatu objek sehingga apabila komponen pengetahuan dan perasaan dinilai baik dan sejalan dengan sikap, ketiga hal tersebut dianggap berhubungan. Namun, apabila terjadi inkonsistensi antara ketiga hal tersebut, hasilnya tidak berhubungan.

Dari penjelasan teori di atas, maka sangat memungkinkan pengetahuan WBP tidak berhubungan dengan perilaku berisiko WBP dalam penularan HIV/AIDS. Walaupun WBP sudah mengetahui tentang risiko penularan HIV/AIDS, akan tetapi dengan adanya pengaruh tekanan sosial, lingkungan sekitar, sangat memungkinkan WBP memiliki perilaku tidak sejalan dengan pengetahuan yang mereka miliki.

\section{b. Hubungan Persepsi Kerentanan dengan Perilaku Pencegahan HIV/AIDS}

Hasil penelitian tentang hubungan persepsi kerentanan dengan perilaku pencegahan HIV/AIDS pada WBP (Warga Binaan Pemasyarakatan), didapatkan data di bawah ini:

Tabel 2.

Hubungan Persepsi Kerentanan dengan Perilaku Pencegahan Penularan HIV/AIDS pada Warga Binaan Pemasyarakatan (WBP) di Lembaga PemasyarakatanKelas IIA Padang Tahun 2018

\begin{tabular}{|c|c|c|c|c|c|c|c|c|}
\hline \multirow{3}{*}{ No } & \multirow{3}{*}{$\begin{array}{c}\text { Persepsi } \\
\text { Kerentanan }\end{array}$} & \multicolumn{4}{|c|}{$\begin{array}{c}\text { Perilaku Pencegahan Penularan } \\
\text { HIV/AIDS }\end{array}$} & \multirow{2}{*}{\multicolumn{2}{|c|}{ Jumlah }} & \multirow{3}{*}{ P Value } \\
\hline & & \multicolumn{2}{|c|}{ Baik } & \multicolumn{2}{|c|}{ Kurang Baik } & & & \\
\hline & & $\mathbf{F}$ & $\%$ & $\mathbf{F}$ & $\%$ & $\mathbf{F}$ & $\%$ & \\
\hline 1 & Baik & 29 & 29 & 29 & 29 & 58 & & \multirow{3}{*}{0,328} \\
\hline 2 & Tidak Baik & 16 & 16 & 26 & 26 & 42 & & \\
\hline & Jumlah & 45 & 45 & 55 & 55 & 100 & 100 & \\
\hline
\end{tabular}


Berdasarkan Tabel 2. dapat diketahui bahwa responden dengan persepsi kerentanan baik lebih banyak memiliki perilaku pencegahan yang baik dalam penularan HIV/AIDS (29\%) dibandingkan responden dengan persepsi kerentanan yang tidak baik (21\%). Hasil uji statistik diperoleh nilai $\mathrm{P}$ Value 0,328 yang berarti tidak terdapat hubungan yang bermakna antara pengetahuan dengan perilaku pencegahan penularan HIV/AIDS.

Berdasarkan Tabel 2. dapat diketahui bahwa responden dengan persepsi kerentanan baik lebih banyak memiliki perilaku pencegahan yang baik dalam penularan HIV/AIDS (29\%) dibandingkan responden dengan persepsi kerentanan yang tidak baik (21\%). Hasil uji statistik diperoleh nilai $\mathrm{P}$ Value 0,328 yang berarti tidak terdapat hubungan yang bermakna antara pengetahuan dengan perilaku pencegahan penularan HIV/AIDS.

Penelitian ini bersebrangan dengan penelitian Wulandari dkk. (2016) menunjukan bahwa ada pengaruh antara persepsi kerentanan dengan perilaku pencegahan IMS pada WPS di Banjarsari Surakarta secara signifikan $\mathrm{p}=0.012$, dimana semakin kuat persepsi kerentanan seorang WPS, maka akan semakin besar kemungkinan memiliki perilaku sehat dalam pencegahan IMS. Gielen dkk. (2016) juga menyatakan bahwa keyakinan terhadap kerentanan muncul sebagai korelasi yang paling signifikan dengan perilaku berisiko seperti berhubungan seksual lebih jarang, tidak melakukan hubungan seksual dan membawa kondom pada wanita. Penelitian Ghaffari dkk. (2017) juga menyatakan bahwa terdapat hubungan antara persepsi kerentanan dengan perilaku pencegahan penularan HIV/AIDS pada kalangan anak muda. Penelitian Krisitianti dkk. (2012) juga menunjukkan adanya hubungan antara persepsi kerentanan IMS dan HIV-AIDS dengan praktek menggunakan kondom pada pelanggan WPS di Semampir Kediri.

Penelitian ini tidak menunjukkan adanya hubungan yang bermakna antara persepsi kerentanan dengan perilaku berisiko penularan HIV/AIDS. Walaupun WBP memiliki anggapan terhadap kerentanan untuk tertular HIV/AIDS, akan tetapi perilaku tetap tidak sesuai dengan persepsi mereka, dikarenakan mereka berada di lingkungan yang memaksa mereka untuk bertindak tidak sesuai dengan apa yang mereka persepsikan.

\section{c. Hubungan Persepsi Keparahan dengan Perilaku Pencegahan Penularan HIV/AIDS}

Hasil penelitian tentang hubungan persepsi keparahan dengan perilaku pencegahan HIV/AIDS pada WBP (Warga Binaan Pemasyarakatan), didapatkan data di bawah ini:

Tabel 3.

Hubungan Persepsi Keparahan dengan Perilaku Pencegahan Penularan HIV/AIDS pada Warga Binaan Pemasyarakatan (WBP) di Lembaga Pemasyarakatan Kelas IIA Padang Tahun 2018

\begin{tabular}{|c|c|c|c|c|c|c|c|c|}
\hline \multirow{3}{*}{ No } & \multirow{3}{*}{$\begin{array}{l}\text { Persepsi } \\
\text { Keparahan }\end{array}$} & \multicolumn{4}{|c|}{$\begin{array}{c}\text { Perilaku Pencegahan Penularan } \\
\text { HIV/AIDS }\end{array}$} & \multirow{2}{*}{\multicolumn{2}{|c|}{ Jumlah }} & \multirow[t]{2}{*}{ P Value } \\
\hline & & \multicolumn{2}{|c|}{ Baik } & \multicolumn{2}{|c|}{ Kurang Baik } & & & \\
\hline & & $\mathbf{F}$ & $\%$ & $\mathbf{F}$ & $\%$ & $\mathbf{F}$ & $\%$ & \multirow{4}{*}{0,658} \\
\hline 1 & Baik & 20 & 20 & 28 & 28 & 48 & 48 & \\
\hline 2 & Tidak Baik & 25 & 25 & 27 & 27 & 52 & 52 & \\
\hline & Jumlah & 45 & 45 & 55 & 55 & 100 & 100 & \\
\hline
\end{tabular}


Berdasarkan Tabel 3. dapat diketahui bahwa responden dengan persepsi keparahan yang baik lebih sedikit memiliki perilaku pencegahan yang baik dalam penularan HIV/AIDS (20\%) dibandingkan responden persepsi keparahan tidak baik (25\%). Hasil uji statistik diperoleh nilai $\mathrm{P}$ Value 0,658 yang berarti tidak terdapat hubungan yang bermakna antara persepsi keparahan dengan perilaku pencegahan penularan HIV/AIDS.

Berdasarkan Tabel 3. dapat diketahui bahwa responden dengan persepsi keparahan yang baik lebih sedikit memiliki perilaku pencegahan yang baik dalam penularan HIV/AIDS (20\%) dibandingkan responden persepsi keparahan tidak baik (25\%). Hasil uji statistik diperoleh nilai $\mathrm{P}$ Value 0,658 yang berarti tidak terdapat hubungan yang bermakna antara persepsi keparahan dengan perilaku pencegahan penularan HIV/AIDS.

Penelitian ini tidak sejalan dengan penelitian Barus (2017) yang menunjukkan bahwa adanya persepsi keseriusan terhadap dampak HIV dengan perilaku berisiko (penggunaan kondom) pada PSK di wilayah kerja Puskesmas Bandar Baru tahun 2015. Penelitian ini uga bersebrangan dengan penelitian (Wulandari dkk., 2016) yang menyatakan bahwa terdapat adanya pengaruh antara persepsi keparahan dengan perilaku pencegahan IMS (Infeksi Menular Seksual) pada WPS (Wanita Pekerja Seks) di Banjarsari Surakarta, dimana semakin kuat persepsi keparahan seorang WPS, maka akan semakin besar kemungkinan memiliki perilaku sehat dalam pencegahan IMS.

Tidak adanya hubungan antara persepsi keparahan dengan perilaku pencegahan penularan HIV/AIDS pada penelitian ini kemungkinan disebabkan oleh karena faktor lain. Walaupun beberapa WBP menganggap memiliki persepsi serius terhadap keparahan penularan penyakit HIV/AIDS, akan tetapi WBP masih banyak yang memiliki perilaku yang tidak baik dalam pencegahan penularan HIV/AIDS. Perilaku ini didorong oleh lingkungan WBP yang tidak sehat dan dorongan dari teman sekitar WBP yang menyebabkan WBP tidak berperilaku sesuai dengan apa yang mereka persepsikan.

Seseorang harus merasakan HIV /AIDS sebagai infeksi serius, sehingga memiliki konsekuensi dan implikasi yang parah pada fisik mereka dan kehidupan sosial, sebelum mereka mengadopsi tindakan pencegahan (seperti penggunaan kondom yang konsisten) terhadap infeksi HIV / AIDS (Tarkang and Zotor, 2015).

\section{d. Hubungan Persepsi Manfaat dengan Perilaku Pencegahan Penularan HIV/AIDS}

Hasil penelitian tentang hubungan persepsi manfaat dengan perilaku pencegahan HIV/AIDS pada WBP (Warga Binaan Pemasyarakatan) dapat dilihat pada Tabel 4:

Tabel 4.

Hubungan Persepsi Manfaat dengan Perilaku Pencegahan Penularan HIV/AIDS pada Warga Binaan Pemasyarakatan (WBP) di Lembaga Pemasyarakatan Kelas IIA Padang Tahun 2018

\begin{tabular}{|c|c|c|c|c|c|c|c|c|}
\hline \multirow{3}{*}{ No } & \multirow{3}{*}{ Persepsi Manfaat } & \multicolumn{4}{|c|}{$\begin{array}{c}\text { Perilaku Pencegahan Penularan } \\
\text { HIV/AIDS }\end{array}$} & \multirow{2}{*}{\multicolumn{2}{|c|}{ Jumlah }} & \multirow{3}{*}{ P Value } \\
\hline & & \multicolumn{2}{|c|}{ Baik } & \multicolumn{2}{|c|}{ Kurang Baik } & & & \\
\hline & & $\mathbf{F}$ & $\%$ & $\mathbf{F}$ & $\%$ & $\mathbf{F}$ & $\%$ & \\
\hline 1 & Baik & 28 & 28 & 30 & 30 & 58 & 58 & \multirow{3}{*}{0,569} \\
\hline 2 & Tidak Baik & 17 & 17 & 25 & 25 & 42 & 42 & \\
\hline & Jumlah & 45 & 45 & 55 & 55 & 100 & 100 & \\
\hline
\end{tabular}


Berdasarkan Tabel 4. dapat diketahui bahwa responden dengan persepsi manfaat yang baik lebih banyak memiliki perilaku pencegahan yang baik dalam penularan HIV/AIDS (28\%) dibandingkan responden persepsi manfaat tidak baik (17\%). Hasil uji statistik diperoleh nilai $\mathrm{P}$ Value 0,569 yang berarti tidak terdapat hubungan yang bermakna antara persepsi manfaat dengan perilaku pencegahan penularan HIV/AIDS.

Persepsi manfaat yang dirasakan mengacu pada keyakinan seseorang dalam kemanjuran tindakan yang disarankan untuk mengurangi risiko atau keseriusan dampak (Resource Centre fo Adolescent Pregnancy Prevention, 2007). Berdasarkan Tabel 4. dapat diketahui bahwa responden dengan persepsi manfaat yang baik lebih banyak memiliki perilaku pencegahan yang baik dalam penularan HIV/AIDS (28\%) dibandingkan responden persepsi manfaat tidak baik (17\%). Hasil uji statistik diperoleh nilai $\mathrm{P}$ Value 0,569 yang berarti tidak terdapat hubungan yang bermakna antara persepsi manfaat dengan perilaku pencegahan penularan HIV/AIDS.

Penelitian ini tidak sejalan dengan penelitian Wulandari dkk. (2016) yang menunjukkan bahwa adanya pengaruh persepsi manfaat dengan perilaku pencegahan IMS pada WPS di Banjarsari Surakarta. Penelitian ini juga tidak sejalan dengan penelitian Enggarwati (2015) yang menujukkan adanya hubungan antara persepsi manfaat dengan perilaku pencegahan penularan HIV/AIDS pada waria pekerja seks di Kabupaten Kudus tahun 2015.

Menurut asumsi peneliti, tidak adanya hubungan antara persepsi manfaat dengan perilaku pencegahan penularan HIV/AIDS pada WBP di Lapas Kelas IIA Padang kemungkinan disebabkan oleh lingkungan WBP sebelum WBP masuk ke Lapas kelas IIA Padang. Walaupun, sebagian besar WBP sudah banyak memiliki persepsi manfaat yang baik, tapi sebagian besar WBP tetap banyak yang melakukan perilaku berisiko penularan HIV/IDS. Adanya dorongan lingkungan sekitar WBP, menyebabkan WBP tetap melakukan perilaku berisiko HIV/AIDS.

\section{e. Hubungan Persepsi Hambatan dengan Perilaku Pencegahan Penularan HIV/AIDS}

Hasil penelitian tentang hubungan persepsi hambatan dengan perilaku pencegahan HIV/AIDS pada WBP (Warga Binaan Pemasyarakatan) dapat dilihat pada Tabel 5:

Tabel 5.

Hubungan Persepsi Hambatan dengan Perilaku Pencegahan Penularan HIV/AIDS pada Warga Binaan Pemasyarakatan (WBP) di Lembaga Pemasyarakatan Kelas IIA Padang Tahun 2018

\begin{tabular}{|c|c|c|c|c|c|c|c|c|}
\hline \multirow{3}{*}{ No } & \multirow{3}{*}{$\begin{array}{c}\text { Persepsi } \\
\text { Hambatan }\end{array}$} & \multicolumn{4}{|c|}{$\begin{array}{c}\text { Perilaku Pencegahan Penularan } \\
\text { HIV/AIDS } \\
\end{array}$} & \multirow{2}{*}{\multicolumn{2}{|c|}{ Jumlah }} & \multirow{3}{*}{ P Value } \\
\hline & & \multicolumn{2}{|c|}{ Baik } & \multicolumn{2}{|c|}{ Kurang Baik } & & & \\
\hline & & $\mathbf{F}$ & $\%$ & $\mathbf{F}$ & $\%$ & $\mathbf{F}$ & $\%$ & \\
\hline 1 & Baik & 9 & 9 & 32 & 32 & 41 & 41 & \multirow{3}{*}{0,000} \\
\hline 2 & Tidak Baik & 36 & 36 & 23 & 23 & 59 & 59 & \\
\hline & Jumlah & 45 & 45 & 55 & 55 & 100 & 100 & \\
\hline
\end{tabular}

Berdasarkan Tabel 5. dapat dibandingkan responden persepsi diketahui bahwa responden dengan hambatan tidak baik (36\%). Hasil uji persepsi hambatan yang baik lebih sedikit statistik diperoleh nilai $\mathrm{P}$ Value 0,000 memiliki perilaku pencegahan yang baik yang berarti terdapat hubungan yang dalam penularan HIV/AIDS (9\%) bermakna antara persepsi hambatan 
dengan perilaku pencegahan penularan HIV/AIDS.

Berdasarkan Tabel 5. dapat diketahui bahwa responden dengan persepsi hambatan yang baik lebih sedikit memiliki perilaku pencegahan yang baik dalam penularan HIV/AIDS (9\%) dibandingkan responden persepsi hambatan tidak baik (36\%). Hasil uji statistik diperoleh nilai $\mathrm{P}$ Value 0,000 yang berarti terdapat hubungan yang bermakna antara persepsi hambatan dengan perilaku pencegahan penularan HIV/AIDS.

Persepsi hambatan merupakan hambatan yang dirasakan mengacu pada keyakinan seseorang pada kenyataan dan biaya psikologis atas perilaku yang disarankan (Resource Centre fo Adolescent Pregnancy Prevention, 2007). Penelitian ini sejalan dengan penelitian Wulandari dkk. (2016) yang menunjukkan adanya pengaruh antara persepsi hambatan dengan perilaku pencegahan IMS pada WPS di Banjarsari Surakarta. Penelitian ini juga didukung oleh Ghaffari (2017) yang menyatakan bahwa adanya hubungan yang signifikan dan tidak langsunga antara hambatan yang dirasakan dengan perilaku pencegahan penularan HIV/AIDS (tidak melakukan hubungan seksual sebelum menikah) pada pemuda di Shiraz, Iran. Dengan meningkatnya hambatan yang dirasakan, niat seseorang untuk tidak melakukan hubungan seksual pranikah akan berkurang.

Menurut peneliti, dengan adanya hubungan antara persepsi hambatan dengan perilaku pencegahan penularan HIV/AIDS pada WBP di Lapas Kelas IIA Padang, maka disarankan kepada pengelola Lapas untuk menginformasikan tentang bahaya penularan HIV/AIDS kepada WBP dengan memperhatikan hambatan-hambatan yang akan dirasakan oleh WBP ketika WBP akan melakukan perilaku berisiko penularan HIV/AIDS.

\section{f. Hubungan Dorongan dengan Perilaku Pencegahan Penularan HIV/AIDS}

Hasil penelitian tentang hubungan dorongan dengan perilaku pencegahan HIV/AIDS pada WBP (Warga Binaan Pemasyarakatan) dapat dilihat pada Tabel 6.

Tabel 6.

Hubungan Dorongan dengan Perilaku Pencegahan Penularan HIV/AIDS pada Warga

Binaan Pemasyarakatan (WBP) di Lembaga

Pemasyarakatan Kelas IIA Padang Tahun 2018

\begin{tabular}{|c|c|c|c|c|c|c|c|c|}
\hline \multirow{3}{*}{ No } & \multirow{3}{*}{$\begin{array}{c}\text { Persepsi } \\
\text { Dorongan }\end{array}$} & \multicolumn{4}{|c|}{$\begin{array}{c}\text { Perilaku Pencegahan Penularan } \\
\text { HIV/AIDS }\end{array}$} & \multirow{2}{*}{\multicolumn{2}{|c|}{ Jumlah }} & \multirow{3}{*}{ P Value } \\
\hline & & \multicolumn{2}{|c|}{ Baik } & \multicolumn{2}{|c|}{ Kurang Baik } & & & \\
\hline & & $\mathbf{F}$ & $\%$ & $\mathbf{F}$ & $\%$ & $\mathbf{F}$ & $\%$ & \\
\hline 1 & Baik & 23 & 23 & 14 & 14 & 37 & 37 & \multirow{3}{*}{0,015} \\
\hline 2 & Tidak Baik & 22 & 22 & 41 & 41 & 63 & 63 & \\
\hline & Jumlah & 45 & 45 & 55 & 55 & 100 & 100 & \\
\hline
\end{tabular}

Berdasarkan Tabel 6. dapat diketahui bahwa responden dengan persepsi dorongan yang baik lebih banyak memiliki perilaku pencegahan yang baik dalam penularan HIV/AIDS (23\%) dibandingkan responden persepsi hambatan tidak baik (22\%). Hasil uji statistik diperoleh nilai $\mathrm{P}$ Value 0,015 yang berarti terdapat hubungan yang bermakna antara persepsi dorongan dengan perilaku pencegahan penularan HIV/AIDS.

Berdasarkan Tabel 6. dapat diketahui bahwa responden dengan persepsi dorongan yang baik lebih banyak memiliki perilaku pencegahan yang baik 
dalam penularan HIV/AIDS (23\%) dibandingkan responden persepsi hambatan tidak baik (22\%). Hasil uji statistik diperoleh nilai $\mathrm{P}$ Value 0,015 yang berarti terdapat hubungan yang bermakna antara persepsi dorongan dengan perilaku pencegahan penularan HIV/AIDS.

Penelitian ini sejalan dengan penelitian Wulandari dkk. (2016) yang menyatakan bahwa adanya hubungan antara stimulus/dorongan untuk bertindak dengan perilaku pencegahan IMS pada WPS di Banjarsari Surakarta. Penelitian ini juga didukung oleh Enggarwati (2015) yang menyatakan adanya hubungan antara stimulus/dorongan untuk bertindak dengan Perilaku Pencegahan Penularan HIV/AIDS pada Waria Pekerja Seks Di Kabupaten Kudus Tahun 2015.

Menurut asumsi peneliti, dengan adanya hubungan antara dorongan dengan perilaku pencegahan penularan HIV/AIDS pada WBP di Lapas Kelas IIA Padang, maka sangat disarankan kepada pengelola Lapas agar selalu memberikan dorongan yang positif kepada WBP agar mendapatkan informasi tentang penularan HIV/AIDS

\section{KESIMPULAN}

Hasil penelitian menunjukkan adanya hubungan antara persepsi hambatan dan dorongan dengan perilaku pencegahan penularan HIV/AIDS pada WBP di Lapas Kelas IIA Padang. Hasil penelitian juga menunjukkan tidak adanya hubungan antara pengetahuan, persepsi kerentanan, persepsi keparahan, dan persepsi manfaat dengan perilaku pencegahan penularan HIV/AIDS pada WBP di Lapas Kelas IIA Padang.

\section{UCAPAN TERIMA KASIH}

Peneliti mengucapkan terima kasih kepada Kemeristek dikti RI selaku pemberi dana hibah penelitian, Lembaga Layanan Pendidikan Tinggi (LLDIKTI) Wilayah X (Sumatera Barat, Riau, Jambi dan Kepulauan Riau), Rektor Universitas Baiturrahmah, Dekan, Dosen dan Staf akademik Fakultas Kesehatan Masyarakat Universitas Baiturrahmah yang telah banyak memberikan dukungan dalam penelitian ini.

\section{DAFTAR PUSTAKA}

Agha, S., Karlyn, A. \& Meekers. D (2001). The promotion of condom use in nonregular sexual partnerships in urban Mozambique. Health Policy and Planning, vol. 16(2),1pp. 44- 151.

Azwar, S. (2013). Sikap Manusia: Teori dan Pengukurannya. Pustaka Pelajar, Yogyakarta.

Barus, D, J. (2017). Hubungan Komponen Health Belief Model (HBM) dengan Penggunaan Kondom pada Pekerja Seks Komersil (PSK) di Wilayah Kerja Puskesmas Bandar Baru Tahun 2015. Jurnal Mutiara Kesehatan. Volume 1 No. 2 Juni 2017.

Enggrawati, I.H. (2015). Faktor-Faktor yang Berhubungan dengan Perilaku Pencegahan Penularan HIV/AIDS pada Waria Pekerja Seks Di Kabupaten Kudus Tahun 2015. Skripsi. Universitas Negeri Semarang. Semarang.

Erniwaty. (2017). Hubungan Pengetahuan dan Sikap terhadap Perilaku Pencegahan HIV/AIDS pada Warga Binaan Lembaga Pemasyarakatan (LAPAS) 2A Pontianak Tahun 2016. Diakses dari www.jurnal.untan.ac.id pada tanggal 31 Juli 2018. 
Ghaffari, M., Gharlipour, Z., \& Rakhshanderou, S. (2016). Related Factors of the Preventing Behaviors of HIV/AIDS among Young People: Apllying the Extended Health Believe Model (EHBM). Int J Pediatr. Vol. 4 N.8, Serial No. 32, Aug 2016.

Gielen AC, Faden RR, O’Campo P, Kass K, Anderson J. (2016). Women's protective sexual behaviors: a test of the Health Belief Model. AIDS Educ Prev 1994;6:111.

Handayani, Dwi. (2014). Perilaku Warga Binaan Pemasyarakatan dalam Pencegahan HIV/AIDS di Lembaga Pemasyarakatan Narkotika Kelas IIA Kota Bandar Lampung. Fakultas Kesehatan Masyarakat Universitas Diponegoro, Semarang. Skripsi. Diakses dari www.eprints.undip.ac.id pada tanggal 14 Agustus 2018.

Kemenkes RI. (2017). Laporan Perkembangan HIV-AIDS dan Penyakit Infeksi Menular Seksual (PMS) Triwulan I Tahun 2017. Diakses dari: http://www.siha.depkes.go.id pada tanggal 1 Agustus 2018. -. (2011). Surveilans Terpadu Biologis Perilaku 2011. Jakarta.

Kemenkumham. (2012). Pedoman Layanan Komprehensif HIV-AIDS \& IMS di Lapas, Rutan, dan Bapas.

Kristianti, S., Shaluhiyah, Z., \& Nugraha, P. (2012). Perilaku Penggunaan Kondom Pada Pelanggan WPS di Semampir Kediri. Jurnal Promosi Kesehatan Indonesia Vol. 7 / No. 1 / Januari 2012. Diakses dari: https://ejournal.undip.ac.id/index.php/jpki/article/viewFile/18776/13119pada tanggal 1 Desember 2019.

Nurachmah, E. \& Mustikasari. (2009). Faktor pencegahan HIV/AIDS Akibat perilaku berisiko tertular pada siswa SLTP. Fakultas Ilmu Keperawatan, Universitas Indonesia, Depok, Indonesia. Makara, kesehatan, Volume 13, Nomor 2, Desember 2009: 63-68.

Nuzzillah, N.A \& Sukendra, D.M. (2017). Analisis Pengetahuan dan Sikap Narapidana Kasus terhadap Perilaku Berisiko Penularan HIV/AIDS. Jurnal of Health Education. JHE 2 (1) (2017).

Purba, E., Yustina, I., \& Fauzi. (2012). Pengaruh Karakteristik Penghuni Lapas terhadap Tindakan Berisiko HIV/AIDS di Lapas Kelas IIB Lubuk Pakam. Jurnal Kebijakan, Promosi Kesehatan dan Biostatistika. Diakses dari: http://www.download.portalgaruda.org pada tanggal 10 Mei 2018

Reseource Centre for Adolescent Pregnancy Prevention. (2005). Theories and Approaches: Health Believe Model. Diakses dari www.etr.org//recapp/theories/hbm/ pada tanggal 16 Agustus 2018.

Resource Centre fo Adolescent Pregnancy Prevention. (2007). Diakses dari www.etr.org/recapp/theories/hbm/index.htm pada tanggal 16 Agustus 2018.

Situmeang, B., Syarif, S., \& Mahkota, R. (2017). Hubungan Pengetahuan HIV/AIDS dengan Stigma terhadap Orang dengan HIV/AIDS di Kalangan Remaja 15-19 Tahun di Indonesia (Analisis Data SDKI Tahun 2012). Artikel Penelitian. Jurnal Epidemiologi Kesehatan Indonesia. Volume 1, Nomor 2 Juli 2017.

Tarkang, E.E. \& Zotor, F.B. (2015). Application of the Health Belief Model (HBM) in HIV Prevention: A Litetature Review. Central African Journal of Public Health 2015; 1 (1): 1-8.

UNAIDS. (2017). UNAIDS Data 2017. Diakses dari http://www.unaids.org pada tanggal Agustus 2018. 
Wulandari, Y. A., Suryani, N., \& Poncorini, E. (2016). Health Belief Model: Health Preventive Behavior of Sexually Transmitted Infection in Female Sex Workers in Surakarta. Journal of Health Promotion and Behavior (2016), 1 (2): 70-78. 